\title{
OCCURRENCE OF BACILLUS CEREUS IN SOME MILK-BASED DESSERTS
}

\author{
WALLAA F. AMIN \\ Department of Food Hygiene, Faculty of Vet. Med., Assiut University, Egypt
}

Received: 13 December 2017; $\quad$ Accepted: 31 December 2017

\begin{abstract}
A total of one hundred and fifty milk-based desserts samples including rice with milk, pudding, and custard (50 each) were collected from different localities in Assiut city, Egypt. The collected samples were examined for the isolation and enumeration of Bacillus cereus. The Most Probable Number technique was used for the enumeration of Bacillus cereus using tryptone soy polymyxin broth and Mannitol Egg Yolk Polymyxin (MYP) agar. The incidence of Bacillus cereus was $62 \%, 44 \%$ and $32 \%$ in the examined rice with milk, pudding, and custard samples, respectively. The Bacillus cereus count in most of the examined samples was in the range of $10-<10^{2} \mathrm{CFU} / \mathrm{g}$. The public health importance of Bacillus cereus was also discussed.
\end{abstract}

Key words: Bacillus cereus, rice with milk, pudding, custard.

\section{INTRODUCTION}

Bacillus cereus is a Gram-positive, aerobic spore-forming bacilli, commonly present in various natural environments and food matrices (Fiedoruk et al., 2017). B. cereus is responsible for causing diarrhea, emesis, fatal meningitis, and spoilage of different food products (Evreux et al., 2007).

Bacillus cereus food poisoning has two forms; the diarrheal form which is caused by ingesting large numbers of bacterial cells or their spores in a contaminated food, and the emetic form caused by ingesting food contaminated with the preformed toxin. The diarrheal type is primarily manifested by abdominal cramps and diarrhea following an 8 to 16 hrs incubation period (Murray et al., 2007). The emetic form is commonly caused by a toxin (cereulide), which is heat stable causing nausea and vomiting 1-5 hrs after consumption (Hoton et al., 2005). The similarities between the symptoms of the emetic disease and Staphylococcus aureus intoxication and the similarities between the diarrheal disease and that caused by Clostridium perfringens type A food poisoning create confusion to distinguish B. cereus food poisoning (Stenfors et al., 2008).

While there are various estimates of the number of $B$. cereus cells required to cause illness, there is a general agreement that foods containing $<10^{3} \mathrm{CFU} / \mathrm{g}$ are safe for human consumption (Vilas-Boas et al., 2007). Meanwhile, it is reported that $B$. cereus should

Corresponding author: Dr. WALLAA F. AMIN

E-mail address:wallaa 800@yahoo.com

Present address: Department of Food Hygiene, Faculty of Vet. Med., Assiut University, Egypt be $10^{5}-10^{8} \mathrm{CFU} / \mathrm{g}$ in order to cause emetic or diarrheal illness (EFSA, 2005). Although, a small dose $\left(<10^{3} \mathrm{CFU} / \mathrm{g}\right)$ may cause disease in susceptible individuals (Szabo et al., 1984). B. cereus food poisoning results from consumption of contaminated foods, as well as improper handling, storage and cooling of cooked foodstuffs (Schneider et al., 2004). Under improper storage conditions of food after cooking, the spores germinate and the vegetative cells multiply (Logan, 2011).

Presence of $B$. cereus in the dairy products is not only of concern as a public health hazard but also as a cause of economic losses through the reduction of shelf life and the spoilage of the contaminated products. It produces spoilage enzymes such as proteases, lipases, and lecithinases (Fagerlund et al., 2004), it causes bitter-rotten off-flavors due to the protease activity and fruity-rancid off-flavors due to the lipolytic activity (Stenfors et al., 2008).

B. cereus forms resistant spores that spread easily; therefore there is a risk in its transmission through processed, pasteurized, sterilized, and heat-treated food products (Kotiranta et al. 2000). Specific food types tend to be associated with illnesses caused by $B$. cereus. Desserts and dairy products are most frequently the vehicles for the transmission of the diarrheal form of the illness, whereas rice is the main vehicle of the emetic illness. The emergence of psychrotrophic and thermophilic species may mean that $B$. cereus will be of increasing concern to the food industry in the future (Griffiths and Schraft, 2017). It is believed that growth of psychrotrophic strains to high numbers in refrigerators is more significant than toxin production at low temperatures. Moreover, the psychrotrophic strains often limit the 
keeping quality of pasteurized milk and its products (Adams and Moss, 2008).

Because of the ubiquitous distribution of B. cereus in the environment, the prevention of food contamination with the organism or its spores is almost impossible. However, high numbers of $B$. cereus are needed in the food for the food-borne disease to occur, this is frequently associated with holding food under conditions allowing active growth of the organism; it could be through poor refrigeration, slow or inadequate cooling, or holding food warm below $60^{\circ} \mathrm{C}$. Therfore, control measures should be directed to prevent spore germination and to prevent the growth of vegetative cells, which might be the approach to effectively prevent and control the spread of this pathogen. Thorough cooking of foods will likely destroy the vegetative cells and spores, however, heat treatment below $100^{\circ} \mathrm{C}$ might not be effective against spores. Also, non-refrigerated storage of food should be avoided and it should be rapidly and efficiently cooled to less than $7^{\circ} \mathrm{C}$ (Griffiths and Schraft, 2017).

Since $B$. cereus has the ability to grow in wide varieties of food, capable of forming heat-resistant spores, and able to produce toxins adapting heat treatment and cold storage, thus posing risks to the consumers. Additionally, cases of B. cereus food poisoning through milk-based desserts have been reported by Johnson (1984); Meer et al. (1991); Andersson et al. (1995); Schoeni and Wang (2005). Because the dairy desserts are widely consumed in Egypt, this study was conducted to determine the occurrence of B. cereus and to evaluate its load in some milk-based desserts sold in Assiut city markets.

\section{MATERIALS AND METHODS}

\section{Sampling}

A total of 150 milk-based desserts samples were collected from different dairies and pastry shops in Assiut city, Egypt. The samples were rice with milk, pudding (Mahallabia in Arabic dialect), and custard
(50 each). Each sample was obtained as sold to the public and dispatched directly to the laboratory with a minimum of delay. The preparation and handling of the samples were done according to APHA (1992).

\section{Isolation of B. cereus}

An appropriate amount of each prepared sample was inoculated into brain heart infusion broth tubes, then was incubated for $24 \mathrm{~h}$ at $30^{\circ} \mathrm{C}$. An aliquot from the incubated tubes was streaked onto a plate of MYP agar and incubated at $30^{\circ} \mathrm{C}$ for $24 \mathrm{~h}$. Pink, lecithinasepositive colonies were transferred to nutrient agar slants and incubated at $30^{\circ} \mathrm{C}$ for $24 \mathrm{~h}$ for further identification.

\section{Enumeration of B. cereus}

Enumeration of $B$. cereus was done using the Most Probable Number technique (MPN) according to Tallent et al. (2012). Eleven grams of the prepared sample was aseptically transferred to $99 \mathrm{ml}$ of sterile $0.1 \%$ peptone water and then thoroughly mixed to be emulsified completely to obtain a dilution $1 / 10$, from which decimal dilutions were prepared. One $\mathrm{ml}$ from the previously prepared dilutions was added to tryptone soy polymyxin broth tubes (3 tubes for each dilution). The inoculated tubes were incubated at $30^{\circ} \mathrm{C}$ for $48 \mathrm{~h}$. Loopfulls from the positive tubes were streaked onto Mannitol Egg Yolk Polymyxin (MYP) agar plates and incubated at $30^{\circ} \mathrm{C}$ for $24 \mathrm{~h}$. The MPN of $B$. cereus/g of sample was obtained using the MPN table (Peeler et al., 1992).

\section{IV- Identification of the isolates}

The isolated organisms were identified microscopically and biochemically according to (Procop et al., 2017). The biochemical tests used for the identification were motility, catalase, nitrate reduction, citrate utilization, gelatin hydrolysis and indole tests. The identified B. cereus strains were large Gram-positive rods with non-swelling spore, produce lecithinase and do not ferment mannitol on MYP agar, reduce nitrate to nitrite and indole negative. They were motile, catalase positive, citrate utilization positive and gelatin hydrolysis positive.

\section{RESULTS}

Table 1: Incidence of B. cereus in the examined milk-based desserts samples.

\begin{tabular}{cccc} 
The examined sampless & The positive samples \\
\cline { 2 - 4 } & The of examined samples & No. & $\%$ \\
\hline Rice with milk & 50 & 31 & 62 \\
\hline Pudding & 50 & 22 & 44 \\
\hline Custard & 50 & 16 & 32 \\
\hline
\end{tabular}


Table 2: Frequency distribution of the positive samples based on their B. cereus count.

\begin{tabular}{|c|c|c|c|c|c|c|}
\hline \multirow{2}{*}{$\begin{array}{l}\text { Intervals } \\
\text { CFU/g }\end{array}$} & \multicolumn{2}{|c|}{ Rice with milk } & \multicolumn{2}{|c|}{ Pudding } & \multicolumn{2}{|c|}{ Custard } \\
\hline & No. & $\%$ & No. & $\%$ & No. & $\%$ \\
\hline $3-<10$ & - & - & 3 & 13.64 & 3 & 18.75 \\
\hline $10-<10^{2}$ & 19 & 61.29 & 15 & 68.18 & 12 & 75 \\
\hline $10^{2}-<10^{3}$ & 10 & 32.26 & 3 & 13.64 & 1 & 6.25 \\
\hline $10^{3}-<10^{4}$ & 2 & 6.45 & 1 & 4.54 & - & - \\
\hline Total & 31 & 100 & 22 & 100 & 16 & 100 \\
\hline
\end{tabular}

Table 3: Microbial quality* of the examined samples based on their B. cereus count.

\begin{tabular}{|c|c|c|c|c|c|c|c|c|}
\hline \multirow{4}{*}{$\begin{array}{c}\text { The examined } \\
\text { samples }\end{array}$} & \multicolumn{8}{|c|}{ B. cereus CFU/g } \\
\hline & \multirow{2}{*}{\multicolumn{2}{|c|}{$\frac{\text { Good }}{<10^{2}}$}} & \multirow{2}{*}{\multicolumn{2}{|c|}{$\frac{\text { Acceptable }}{10^{2}-<10^{3}}$}} & \multirow{2}{*}{\multicolumn{2}{|c|}{$\frac{\text { Unsatisfactory }}{10^{3}-<10^{4}}$}} & \multicolumn{2}{|c|}{ Potentially hazardous } \\
\hline & & & & & & & \multicolumn{2}{|c|}{$\geq 10^{4}$} \\
\hline & No./50 & $\%$ & No./50 & $\%$ & No./50 & $\%$ & No./50 & $\%$ \\
\hline Rice with milk & 38 & 76 & 10 & 20 & 2 & 4 & - & - \\
\hline Pudding & 46 & 92 & 3 & 6 & 1 & 2 & - & - \\
\hline Custard & 49 & 98 & 1 & 2 & - & - & - & - \\
\hline
\end{tabular}

* According to the public health guidelines (NSW Food Authority, 2009)

\section{DISCUSSION}

Milk-based desserts are popular dairy food prepared from ingredients that milk is the basic constituent. They are palatable, nutritious and relatively inexpensive dairy food. These types of desserts are consumed in Egypt by a wide range of people of all ages and are usually served cooled (AL-Gendi, 2004). Rice with milk and pudding (Mahallabia) are the most widely consumed dairy desserts in Egypt (ELShaar, 1993). Milk-based products are good media for the growth of microorganisms because of their high nutritive value, almost neutral $\mathrm{pH}$ and long storage periods (Bell and Kyriakides, 1998). The bacteria most frequently found to contaminate milk-based desserts are members of the Enterobacteriaceae group, Pseudomonas spp., and Bacillus spp. (in particular B. cereus) (Lewis and Dale, 1994).

Dairy-based foods are important means for the transmission of different pathogens especially in places where the hygienic measures are not strictly adopted (Meyer-Broseta et al., 2003). Assessing the exposure to $B$. cereus is an important issue in estimating the risk for food-borne disease by this microorganism. The actual disease symptoms, however, are caused by toxins, either produced during growth in the gut; enterotoxins or during growth in food; emetic toxin (Adams and Moss, 2008).
Dairy desserts in Egypt are locally produced by traditional retail shops and the production takes place manually in stores. Custard is made from highly nutritive raw materials; milk and sugar and is easily spoiled by the multiplication of specific microbial contaminants (Arakawa et al., 2008).

The Most probable number (MPN) technique was used for enumeration of $B$. cereus in this study as it is described in reference methods and is recommended for routine surveillance of products in which small numbers of B. cereus are expected (Bennett et al., 2015).

The results recorded in Table 1 revealed that $B$. cereus was detected in $62 \%, 44 \%$ and $32 \%$ of the examined rice with milk, pudding, and custard samples, respectively. Nearly similar results were recorded by Al- Ashmawy et al. (1996); Reyes et al. (2007), while lower incidence for the rice with milk was recorded by Hassan and Afifi (2016); Mohamed et al. (2016). Also, higher incidence for pudding (Hussein et al., 2015) and lower incidence for custard (Van Netton et al., 1990) were recorded. The different results obtained by researchers can be due to regional, seasonal, sampling and methodological differences. Also, the degree of contamination depends on the precautions observed during processing. 
It is noticeable from Table 2 that most of the positive samples; $61.29 \%$ of the positive rice with milk samples, $68.18 \%$ of the positive pudding samples and $75 \%$ of the positive custard samples were in the range $10-<10^{2} \mathrm{CFU} / \mathrm{g}$. The obtained results are in agreement with that reported by Bryan et al. (1992) and Rosenquist et al. (2005).

The quality of the examined samples regarding the $B$. cereus count was estimated using the guidelines for the microbiological quality of ready-to-eat foods (NSW Food Authority, 2009), which shows four grades of the microbiological quality related to the $B$. cereus count; $<10^{2} \mathrm{CFU} / \mathrm{g}$ is considered good, $10^{2}$ $<10^{3} \mathrm{CFU} / \mathrm{g}$ is considered acceptable, $10^{3}-<10^{4}$ $\mathrm{CFU} / \mathrm{g}$ is considered unsatisfactory and $\geq 10^{4} \mathrm{CFU} / \mathrm{g}$ is considered unacceptable (potentially hazardous). It is clear from the results in Table 3 that $76 \%$ of the examined rice with milk samples, $92 \%$ of the examined pudding samples and $98 \%$ of the examined custard samples were considered good. Furthermore, $20 \%, 6 \%$ and $2 \%$ of the examined rice with milk, pudding, and custard samples, respectively were considered acceptable and only $4 \%$ of the examined rice with milk samples and $2 \%$ of the examined pudding samples were considered unsatisfactory. While, none of the examined samples was considered unacceptable (potentially hazardous). At the detected levels, B. cereus is not considered injurious to health, however, the risk will increase proportional to the detected levels and the likelihood of subsequent growth.

Since milk is the main constituent of the examined samples, it seems to be one of the sources of the contamination with the B. cereus. Soiling of cows' udders is one of the main sources of contamination of milk with $B$. cereus. The control of $B$. cereus in the dairy industry is challenging owing to the numerous points at which milk could get contaminated, either during production or processing. The number of $B$. cereus or its spores may be limited in raw milk by proper cleaning of the udder and teats before milking. It is worth mentioning that pasteurization kills the vegetative bacteria, but the spores survive. Pasteurization might even activate some of the spores (heat activation), which might start germinating (Tewari and Abdullah, 2015). In general, the food production facilities must use heating methods that destroy B. cereus vegetative cells and most spores. Also, cooked food should not be stored at room temperature (Montanhini et al., 2013). While, cold storage may be a suitable control measure for such products. However, up to $14 \%$ of $B$. cereus strains may be psychrotrophic (Granum, 1997), and so temperature alone is not a practical control measure. Milk-based desserts should be prepared in small batches, cooled rapidly, and stored at $4^{\circ} \mathrm{C}$ (Smith et al., 2003).
In conclusion, the examined rice with milk, pudding and custard samples were contaminated with $B$. cereus in different percentages but in low numbers. However, rice with milk was more contaminated than pudding and custard. The current $B$. cereus load is not threatening to health but further growth of the bacteria at the retail premises until selling is likely leading to health hazards. Therefore, it is recommended to adopt measures to minimize the contamination with $B$. cereus from the very outset, even before processing in order to avoid the growth of the organism to dangerous levels. Also, better hygienic practices are required in the production of such products.

\section{REFERENCES}

A.P.H.A. (American Public Health Association) (1992): "Standard Methods for the Examination of Dairy Products". American Public Health Association, $16^{\text {th }} \mathrm{Ed}$.

Adams, M.R. and Moss, M.O. (2008): "Food Microbiology". $3^{\text {rd }}$ Ed. The Royal Society of Chemistry publishing, Cambridge, U.K.

Al-Ashmawy, A.M.; El-Ebeedy, A.A.; El-Gamal, A.M. and Youssef, SH.M. (1996): "Occurrence and enumeration of Bacillus cereus in Egyptian dairy desserts". Assiut Vet. Med. J., 36(71): 117-124.

AL-Gendi, M.N. (2004): "Microbiological evaluation of some locally manufactured dairy desserts in Assiut City". M.V.Sc. Thesis, Assiut University, Egypt.

Andersson, A.; Ronner, U. and Granum P. (1995): "What problems does the food industry have with the spore-forming pathogens Bacillus cereus and Clostridium perfringens". Int. J. Food Microbiol., 28, 145-155.

Arakawa, K.; Kawai,Y.; Iioka, H.; Tanioka, M.; Nishimura, J.; Kitazawa, H.; Tsurumi, K. and Saito, T. (2008): "Microbial Community Analysis of Food-Spoilage Bacteria in Commercial Custard Creams Using CultureDependent and Independent Methods". J. Dairy Science, 91(8): 2938-2946.

Bell, C. and Kyriakides, A. (1998): “A practical approach to the organism and its control in foods". Blackie Academic and Professional, London, UK.

Bennett, R.W.; Tallent, S.M. and Hait, J.M. (2015): "Bacillus cereus and Bacillus cereus toxins" In: Y Salfinger; ML Tortorello (eds). Compendium of Methods for the Microbiological Examination of Foods, $5^{\text {th }}$ Ed. American Public Health Association, Washington DC.

Bryan, F.L.; Teufel, P.; Roohp, S. and Qadar, F. (1992): "Hazards and Critical Control Points of Food Preparation and Storage in Homes in a Village and a Town in Pakistan". J. Food Protection, 55(9): 714-721. 
EFSA, European Food Safety Authority (2005): "Opinion of the Scientific Panel on Biological Hazards on Bacillus cereus and other Bacillus spp in foodstuffs". EFSA Journal; 175: 1-48.

EL-Shaar, M. (1993): "Microbiological studies on dairy desserts in Sharkia Governorate". M.V.Sc. Thesis, Zagazig University, Egypt.

Evreux, F.; Delaporte, B.; Leret, N.; Buffet-Janvresse, C. and Morel, A. (2007): "A case of fatal neonatal Bacillus cereus meningitis," Archives de Pediatrie, 14(4): 365-368.

Fagerlund, A.; Ween, O.; Lund, T.; Hardy, P. and Granum, E. (2004): "Genetic and functional analysis of the cytK family of genes in Bacillus cereus". Microbiology, 150: 2689 2697.

Fiedoruk, K.; Drewnowska, J.M.; Daniluk. T.; Leszczynska, K.; Iwaniuk, P. and Swiecicka, I. (2017): "Ribosomal background of the Bacillus cereus group thermotypes". Sci. Rep. 7, 46430; doi: 10.1038/srep46430. Retrieved from: http://www.nature.com/srep [Accessed 16 ${ }^{\text {th }}$ September, 2017].

Granum, P.E. (1997): "Bacillus cereus". In Food Microbiology - Fundamentals and Frontiers, Doyle, M.P., Beuchat, L.R., and Montville, T.J., Eds., Washington D.C.: ASM Press, Inc., 327-336.

Griffiths, M. and Schraft, H. (2017): "Bacillus cereus Food Poisoning”. Chapter 20. In: Foodborne Diseases. $3^{\text {rd }}$ Ed. Academic press. pp. 395-405.

Hassan, G.M. and Afifi, S.I. (2016): "Bacteriological Quality Assessment of Some Locally Manufactured Dairy Desserts Sold in BeniSuef City, Egypt and Molecular Detection of Staphylococcus aureus Enterotoxin". Zagazig Vet. J., 44(2): 91-100.

Hussein, M.F.; Sadek, O.A. and EL Taher, S.G. (2015): "Occurrence of Bacillus cereus and Staphylococcus aureus organisms in some dairy desserts". Assiut Vet. Med. J., 61(145): 160-165.

Hoton, M.; Andrup, L.; Swiecicka, I. and Mahillon, J. (2005): "The cereulide genetic determinants of emetic Bacillus cereus are plasmid-borne". Microbiology, 151: 2121-2124.

Johnson, K.M. (1984): "Bacillus cereus food borne illness and update”. J. Food Prot., 47, 145-153.

Kotiranta, A.; Lounatmaa, K. and Haapasalo, M. (2000): "Epidemiology and pathogenesis of $B$. cereus infections". Microbes Infect., 2:189198.

Lewis, M. and Dale, R.H. (1994): "Chilled yogurt and other dairy desserts". Shelf Life Evaluation of Foods. Chapter 7, C.M.D. Man et al. (eds.), Chapman \& Hall.

Logan, N.A. (2011): "Bacillus and relatives in foodborne illness". J. Appl. Microbiol., 112: 417-429.

Meer, R.R.; Baker, J.; Bodyfelt, F.W. and Griffiths, N.W. (1991): "Psychrotrophic Bacillus spp. in fluid milk products: A review". J. Food Prot., 54: 969-979.

Meyer-Broseta, S.; Diot, A.; Bastian, S.; Riviere, G. and Cerf, O. (2003): "Estimation of low bacterial concentration: Listeria monocytogenes in raw milk". Int. J. Food Microbiol., 80(1): 1-15.

Mohamed, A.S.; Alnakip, M.E. and Abd-El Aal, S.F. (2016): "Occurrence of B. cereus in raw milk and some dairy products in Egypt". Japanese J. Vet. Res., 64(2): 95-102.

Montanhini, M.T.; Montanhini, R.N.; Pinto, J.P. and Bersot, L.S. (2013): "Effect of temperature on the lipolytic and proteolytic activity of Bacillus cereus isolated from dairy products". Int. Food Res. J., 20(3): 1417-1420.

Murray, P.R.; Baron, E.J.; Jorgensen, J.H.; Landry, M.L. and Pfaller, M.A. (2007): Manual of clinical microbiology, $9^{\text {th }}$ Ed. American Society of Microbiology Press, Washington D.C., USA.

NSW Food Authority (2009): "Microbiological quality guide for ready-to-eat foods". A guide to interpreting microbiological results. http://www.foodauthority.nsw.gov.au/ Docum ents/scienceandtechnical/ microbiological_ quality_guide_for_RTE_food.pdf [Accessed $13^{\text {th }}$ October, 2017].

Peeler, J.T.; Houghtby, G.A. and Rainosek, A.P. (1992): "The most probable number technique". In: Vanderzant, C., Splittstoesser, D.F. (Eds.), Compendium of Methods for the Microbiological Examination of Foods, $3{ }^{\text {rd }} \mathrm{Ed}$. American Public Health Association, Washington D.C., pp. 105-118.

Procop, G.; Church, D.; Hall, G.; Janda, W.; Koneman, E.; Schreckenberger, P. and Woods, G. (2017): "Aerobic and facultative gram positive bacilli". In Koneman's Color Atlas and textbook of Diagnostic Microbiology. $7^{\text {th }}$ ed. Lippincott Williams and Wilkins Company, Philadelphia, USA.

Reyes, E.; Bastias, M.; Gutierrez, R. and Rodriguez, O. (2007): "Prevalence of Bacillus cereus in dried milk products used by children school feeding program". J. Food Microbiol., 24: 1- 6

Rosenquist, H.; Smidt, L.; Andersen, S.R.; Jensen, G.B. and Wilcks, A. (2005): "Occurrence and significance of Bacillus cereus and Bacillus thuringiensis in ready-to-eat food". FEMS Microbiol. Lett., 250: 129-136.

Schneider, K.R.; Parish, M.E.; Goodrich, R.M. and Cookingham, T. (2004): "Preventing Foodborne Illness: Bacillus cereus and Bacillus anthracis". University of Florida, IFAS extension, https://pdfs.semanticscholar. org/f097/525fdce0db8180af17562c7f6f7980e7 acad.pdf [Accessed 19 ${ }^{\text {th }}$ September, 2017].

Schoeni, J.L. and Wang, A.C. (2005): "Bacillus cereus food poisoning and its toxins". J. Food Prot., 68: 636-648. 
Smith, J.P.; Daifas, D.P.; El-Khoury, W. and Austin, J.W. (2003): "Microbial Safety of Bakery Products". In Microbial Safety of Minimally Processed Foods. Novak et al., Ed. Chapter 1. CRC press, Florida, USA. pp. 4-33.

Stenfors, P.; Fagerlund, A. and Granum, E. (2008): "From soil to gut: Bacillus cereus and its food poisoning toxins". FEMS, Microbiol. Rev., 32(4): 579-606.

Szabo, R.A.; Todd, E.C.D. and Rayman, M.K. (1984): "Twenty four hours isolation and confirmation of Bacillus cereus in foods". J. Food Protection, 47: 856-860.

Tallent, S.M.; Rhodehamel, E.J.; Harmon, S.M.; Belay, N., Shah, D.B. and Bennett, R.W.
(2012): “Bacillus cereus". Bacteriological Analytical Manual, Chapter 14.

Tewari, A. and Abdullah, S. (2015): "Bacillus cereus food poisoning: International and Indian perspective". J. Food Sci. Technol., 52(5): 2500-2511.

Van Netten, P.; van de Moosdijk, A.; van Hoensel, P.; Mossel, D.A.A. and Perales, I. (1990): "Psychrotrophic strains of Bacillus cereus producing enterotoxin". Journal of Applied Bacteriology, 69(1): 73-79.

Vilas-Boas, G.T.; Peruca, A.P. and Arantes, O.M. (2007): "Biology and taxonomy of Bacillus cereus, Bacillus anthracis, and Bacillus thuringiensis". Canadian Journal of Microbiology, 53(6): 673- 687.

\section{تواجد الباسيلس سيريس فى بعض الحلاوي لبنية الأساس}

E-mail: wallaa_800@yahoo.com Assiut University web-site:www.aun.edu.eg

تم جمع • إ عينة من الحلاوي لبنية الأساس؛ الأرز باللبن، والمهلبية، والكسترد من مناطق مختلفة في مدينة أسيوط، مصر. وتم فحص العينات التي تم جمعها لعزل و عد الباسيلس سيريس. حيث تم استخدام تقنية MPN لعد الباسيلس سيريس باستخدام soy polymyxin broth

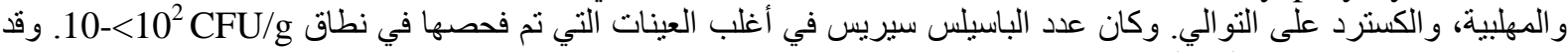
تمت مناقشة خطورة تواجد الباسيلس سيريس.

الكلمات المفتاحية: الباسيلس سيريس، الأرز باللبن، المهلبية، الكسترد. 